SAŠA REDŽIĆ

904:739.2"652”(497.11)

Archaeological Institute

904:726.861"652"(497.11)

Belgrade, Serbia

COBISS.SR-ID 212285196

Sasa.redzic@gmail.com

MLADEN JOVIČIĆ

Archaeological Institute

Original research article

Belgrade, Serbia

Received: December $26^{\text {th }} 2013$

Accepted: February $15^{\text {th }} 2014$

SVETLANA PANTELIĆ

Archaeological Institute

Belgrade, Serbia

\title{
UNPUBLISHED GRAVE-GOODS OF BELT-SETS WITH RING-SHAPED BUCKLES FROM VIMINACIUM
}

\section{ABSTRACT}

The subjects of this paper are two belt-sets discovered in skeletal graves from the Viminacium cemeteries "Više grobalja" and "Rit". They both contained ring-shaped buckles buttoned with buttons with calotte-shaped heads. One of the sets presented here also included a pair of strap terminals with a ring in the middle.

Keywords: belt-sets, grave, Viminacium, buckle, buttons, belt-tongue.

During the excavations of 2013 at the Viminacium sites "Više grobalja" and "Rit”, two graves with skeletal burials were discovered, containing belt-sets with ring-shaped buckles as grave-goods.
At the first site, the grave G-2272 was excavated, with the deceased placed in a simple pit in a crouching position facing right (Fig. 1). Grave-goods consisted of the following objects: buckle (1a), two

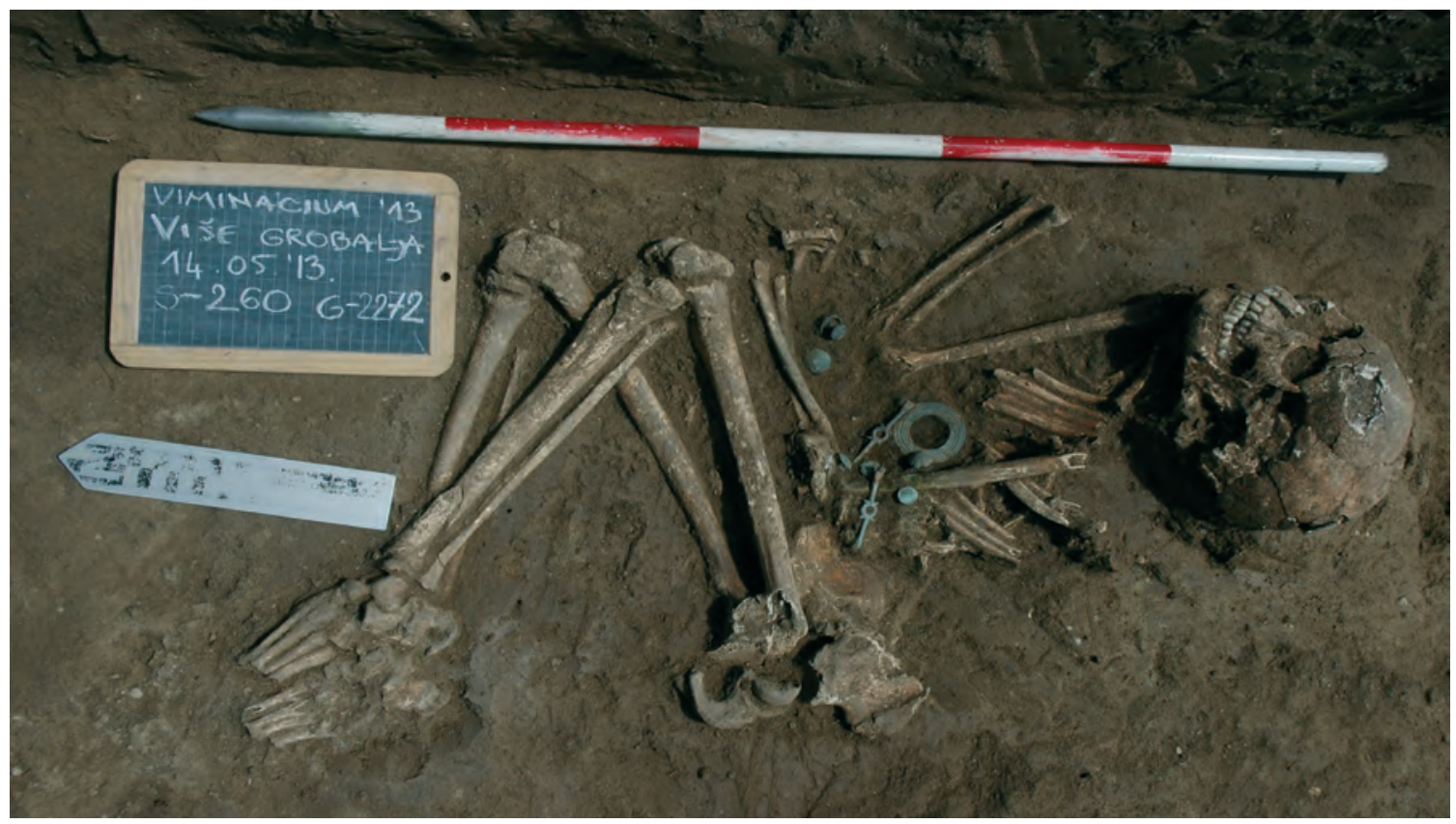

Fig. 1 The site "Više grobalja”, grave G-2272. 


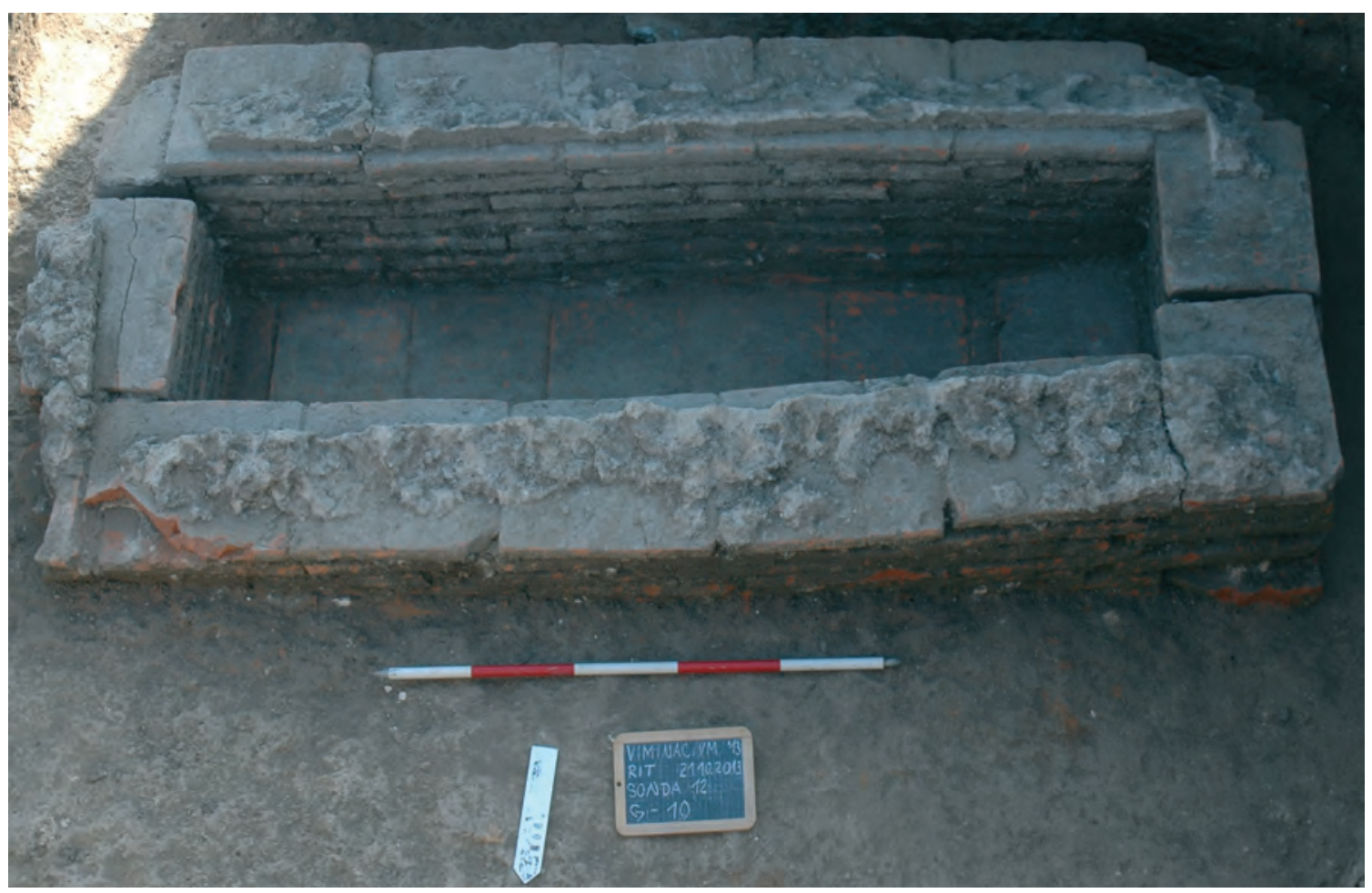

Fig. 2 The site "Rit”, grave G-10.

strap terminals with a ring in the middle (1b-c), three buttons with calotte-shaped heads (1d-f) and three buttons with flat hammered heads (1g-i).

In the second case, grave $\mathrm{G}-10$, constructed from bricks, was discovered at the site "Rit" (Fig. 2). The grave is missing its cover, which certainly existed, and was destroyed during a robbery. This is also the reason due to which the bones of the deceased were dislocated. The grave-goods from this grave consisted of a fragmented buckle (2a), a calotte-shaped button (2b) as well as a coin minted in Nicaea during the second quarter of the 3rd century.

Sets containing ring-shaped buckles, as well as with buttons with calotte-shaped heads were named "Ringschnallencingulum" by J. Oldenstein (Oldenstein 1977: 218-219). The buckles presented here are round and decorated with concentric incisions. In the territory of Serbia, examples of ellipsoidal or round cross-sections without decoration were discovered, along with those decorated with faceting (Redžić 2013: 96-104, T. XIX-XXII, 150-168). They are often discovered with one or more buttons with a calotte-shaped head and a flat base. Images on tombstones were used to reconstruct belt-sets of this type, on which the perforated ends of the belt-straps were pulled through the

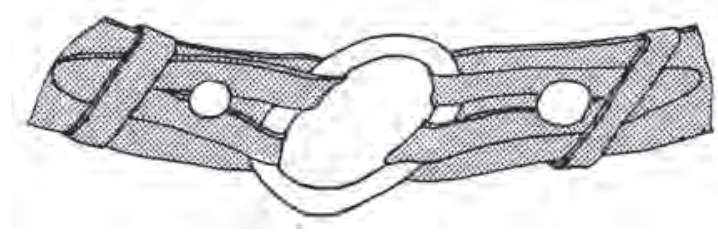

Fig. 3. The method of binding ring-shaped buckles (Oldenstein 1977, 168, Abb.2)

buckle and tied to the buttons, as shown on Figure 3. Since quite a number of buckles were discovered with only one button, it can be presumed that here, perhaps, one side of the strap was tied only by simply being wrapped around the buckle. Proof of this can be found in the image of a horseman from the Vatican museum shown on Figure 4.

Buckles from the territory of Serbia were mostly made of a copper alloy, like the example presented in 1a, but another buckle will also be mentioned which is made of ivory and discovered at the Viminacium site "Pirivoj" (Redžić 2013: 99, T. XIX, 150). Another example, from the site "Više grobalja", and similar to the example presented in 2a, was made of silver (Redžić 2013: 102, T.XXI, 164). Finds of this type are also often encountered outside Serbia, like an example made of bone from Saalburg (Oldenstein 


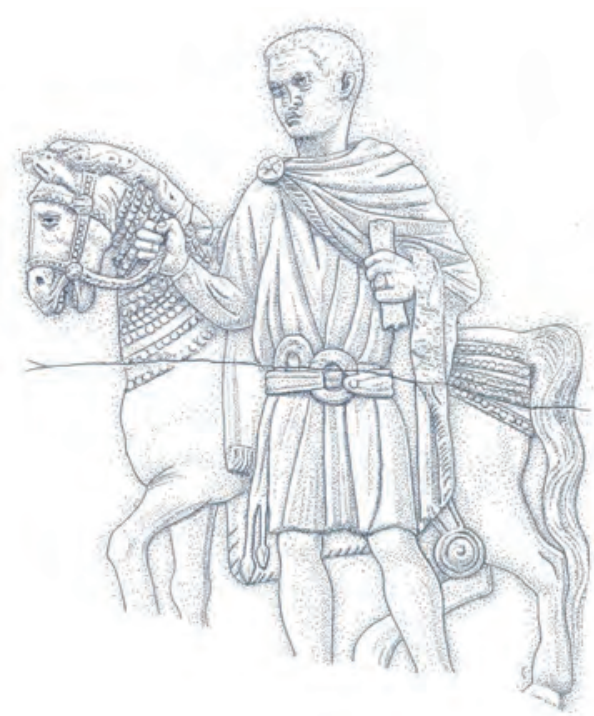

Fig. 4 The method of binding a belt-set with a single button (James 2004,63, Fig. 32, c)

1977: 218, Tafel 79, 1052) and the finds from Intercisa (Oldenstein 1977: 168, footnote 555), Dura Europos (James 2004: 76-77, Fig. 37, 4347), Aquincum (Topál 1993: 12, plate 9, Grave 12, 7,8), Apulum (Ciugudean, Ciugudean 2000: 205-209, Fig. 2).

According to the head shape, buttons can be divided into two variants. The first variant includes buttons with convex heads (1d-f, 2b), while the other includes examples with a flat-hammered head (1g-i) (Redžić 2013: 303-312, T. LXVII-LXVIII, 750-780). What they have in common is a flat base, used for fixing buttons to the base. Apart from being used for buttoning belt-sets, the buttons with convex heads were also included in horse-equipment. This is indicated with their $5-10 \mathrm{~mm}$ long axis, capable of connecting two leather straps. By following this principle, buttons with axes shorter than $5 \mathrm{~mm}$ were most likely used as decoration or possessed some other function, which was common for buttons with flat-hammered heads. Buttons with calotte-shaped heads were used for fixing a sword to a balteus, as shown with an in situ discovery from the site Illerup Adal (Miks 2007: 286287, Abb. 63-64). The two possible reconstructions are shown on Figure 5. A similar situation was confirmed in Viminacium, where these buttons were discovered as parts of belt-sets which included buckles with thorns and knives (Redžić 2013: 305). Since no buttons were used for buttoning such beltsets, we can presume that they were used for fixing

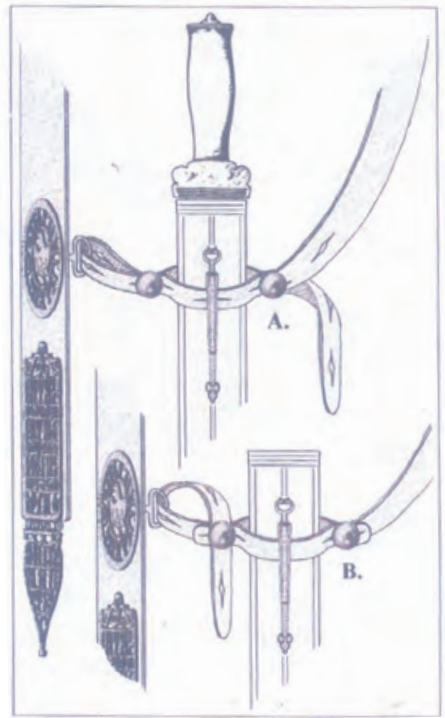

Fig. 5 Two possible methods of fixing swords onto baltea using buttons (Miks 2007, 287, Abb. 64)

knife scabbards to the belt.

Both variants are often encountered in sites throughout the Empire, which makes it redundant to list them individually. Still, a mould for making five pieces of the buttons with calotteshaped heads from Regensburg should be mentioned, indicating the existence of a workshop for their production in this town (Fischer 1988: 188). Just like the examples presented here, most of these finds were made of a copper alloy, while only sporadically, examples were made of bone, ivory or silver.

Strap terminals with a ring in the middle (1bc) were decorated with faceting and had a broader upper axis ending which was perforated to allow it to be put through a leather strap and then fixed with a nail. On the spot where the axis and the ring meet, there are four bulges. Apart from single finds from Dura Europos (James 2004: 85-86, Fig.40, 151) and Apulum (Ciugudean, Ciugudean 2000: 205209, fig. 2; 8, 10), a larger number of strap terminals of this type was discovered in the territory of Serbia, all of them made of a copper alloy (Redžić 2013: 346-351, T. LXXIII-LXXIV, 872-890). According to the examples presented here, as well as the finds from Apulum, we can conclude that they were worn in pairs, just like other types of strap terminals used during the $3^{\text {rd }}$ century.

Since such types of belt-sets and their parts were most frequently discovered along the Roman Limes, we can conclude that their main users were 


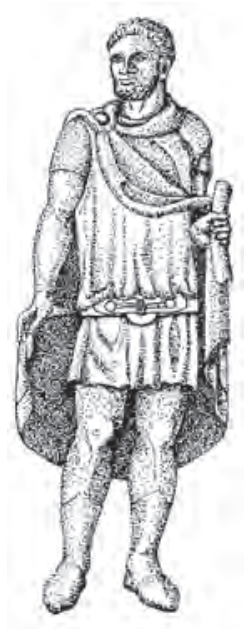

a

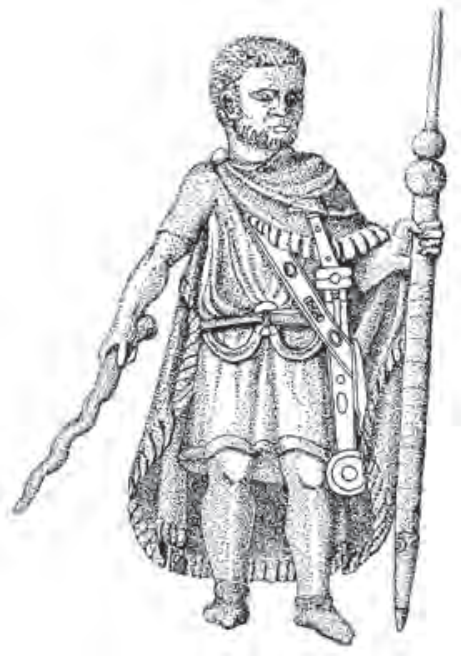

$\mathrm{b}$

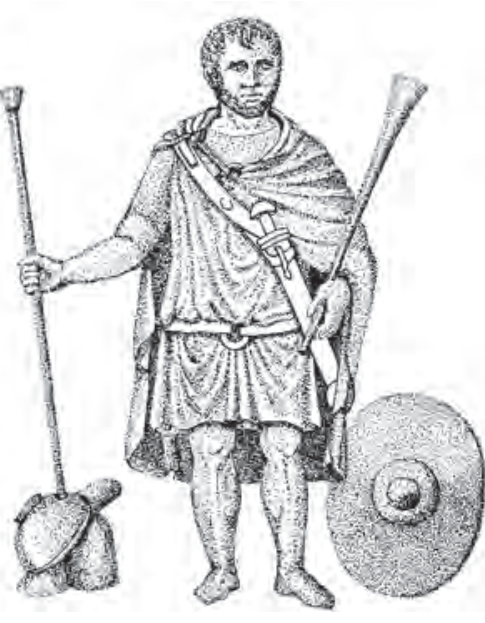

C

Fig. 6. Tombstones with images of soldiers:

a) Tertiolus, b) Aurelius Lucianus, c) Aurelius Suro (Oldenstein 1977, 232, Abb.13, 1a, 2; 233, Abb.14, 2)

soldiers. Direct proof of that are the numerous images on tombstones, some of which are presented in Figure 6. In addition to the tombstones presented here are two sculptures of soldiers from Apulum (Ciugudean, Ciugudean 2000: 214-215, Fig. 4-5), as well as the famous Tarentius' fresco from Bello's temple in Dura Europos, on which at least one soldier wears such a belt-set (James 2004: 41, Fig.19, $\mathrm{G} ; 61$ ). The fact that they were not worn exclusively by soldiers is indicated with finds of such belt-sets in graves of children and women in the cemeteries of Viminacium (Redžić 2013: 97).

A ring-shaped buckle, similar to the examples presented here, from the site Apulum was discovered in grave number 19, along with buttons, a shackle, two fragmented strap terminals with a ring in the middle, a T-shaped fibula and a coin of Faustina II (Ciugudean, Ciugudean 2000: 205-209, fig. 2). According to the find of a T-shaped fibula, the grave was dated into the $3^{\text {rd }}$ century, but according to other finds, it is clear that its dating should be limited to the first half, or at least the beginning of the second half, of the $3^{\text {rd }}$ century. Another belt-set of this type from Apulum was dated into the period from the beginning of the $3^{\text {rd }}$ century until the end of its third quarter by D. Ciugudean (Ciugudean 2010: 454). The same author claims that the earliest dating of a ring-shaped buckle is its image on an altar from Eining, dated into the year 211 (Ciugudean, Ciugudean 2000: 209).
Dating of this type of belt-set from the Viminacium graves is indicated with coins, like the example published here in figures $2 \mathrm{a}-\mathrm{b}$, which was discovered with a coin minted during the second quarter of the $3^{\text {rd }}$ century. Finds from other Viminacium graves were also dated according to numismatic finds. The oldest example was discovered with a coin minted during the shared reign of Marc Aurel and Lucius Verus. The buckle with a bone button was discovered in a grave with a VTERE FELIX fitting and with a coin dated in the $2^{\text {nd }}$ century. A set consisting of a buckle, a button and a shackle was discovered along with two coins, one of them minted during the reign of Caligula and the other during the reign of Emperor Commodus (172-180). In a double grave with buried infants there was a set discovered together with a coin of Geta. Another set was discovered in a grave with a coin of Gordian III, while the youngest set was dated with a coin of Gallienus (Redžić 2013: 97). A more precise dating is also obtained due to the belttongue with a ring in the middle discovered with a coin from Nicaea, and dated into the second quarter of the $3^{\text {rd }}$ century (Redžić 2013: 346).

The great frequency of finds of ring-shaped buckles, buttons, strap terminals with a ring in the middle and fittings that are usually part of the belt sets, in the territory of Serbia, perhaps indicates that there was a production centre in this area. This opinion should at least be accepted as 
a hypothesis, until it is confirmed with a find of a mould or an unfinished product.

\section{CATALOGUE}

1a-i. Ring-shaped buckle, two strap terminals, three buttons with calotte-shaped heads and three buttons with flat-hammered heads made of a copper alloy. The buckle was made of sheet metal and decorated with incisions. The strap terminals are decorated with faceting and they possess a ring in the middle, while their upper ending is perforated to allow it to be put on a leather strap which was then fixed with a nail. On the spot where the ring and the axis meet, there are four bulges. The upper end of one of the three buttons is decorated with radial carvings. The buttons with flat-hammered heads are decorated with carved lines. All of the buttons possess a flat base.

Finding place: Viminacium, Više grobalja, 2013, C-12603;

Dimensions: buckle diameter: $6.2 \mathrm{~cm}$; tongue length: $8 \mathrm{~cm}$; buttons with calotte-shaped head, diameter: $2.1-2.5 \mathrm{~cm}$, height: $1.5-2 \mathrm{~cm}$.

Unpublished.

Discovered in skeletal grave G-2272, in the stomach area.

2a-b. Fragmented ring-shaped buckle made of silver sheet, decorated with incisions, as well as a button with a calotte-shaped head and flat-hammered base made of a copper alloy.

Finding place: Viminacium, Rit, 2013, C-519;

Dimensions: length of the fragmented buckle: $5.8 \mathrm{~cm}$; button: diameter: $2.1 \mathrm{~cm}$, height $2.1 \mathrm{~cm}$.

Unpublished.

Discovered in skeletal grave G-10, along with a coin minted in Nicaea, during the second quarter of the $3^{\text {rd }}$ century.

\section{BIBLIOGRAPHY}

Ciugudean D., Ciugudean, H. 2000

A Roman Military Grave from Apvlvm, Army and Urban Development in the Danubian Provinces of Roman Empire, Bibliotheca Mvsei Apvlensis XV, Alba Iulia: 203-216.
Ciugudean, D. 2010

Un nou mormânt de militar roman din necropola nordică de la Apulum, Apulum XLVII, Alba Iulia: 447-456.

\section{Fischer, T. 1988}

Zur römischen Offizierausrüstung im 3. Jahrhundert n. Ch., Bayerische Vorgeschichtsblätter 53: 167-190.

James, S. 2004

Excavations at Dura-Europos 1928-1937, Final Report VII, The Arms and Armour and other Military Equipment, London 2004.

Miks, C. 2007

Studien zur römischen Schwertbewaffnung in der Kaiserzeit, Leidorf.

Oldenstein, J. 1977

Zur Ausrüstung römischer Auxiliareinheiten, Bericht der Römisch-Germanischen Kommission des Deutschen Archäologischen Instituts 57 (1976), Frankfurt.

Redžić, S. 2013

Rimske pojasne garniture na tlu Srbije od I do IV veka, Doktorska teza u rukopisu, Beograd.

\section{Topál, J. 1993}

Roman cemeteries of Aquincum, Pannonia, Budapest.

\section{REZIME}

\section{NEPUBLIKOVANI GROBNI \\ PRILOZI POJASNIH \\ GARNITURA SA PRSTENASTIM KOPČAMA SA VIMINACIJUMA}

Ključne reči: pojasne garniture, grob, Viminacijum, kopča, dugmad, pojasni jezičak.

Tokom iskopavanja vršenih 2013. godine na viminacijumskim nekropolama „Više grobalja“ i „Rit“ otkrivena su dva groba inhumiranih pokojnika koji su kao prilog imali pojasne garniture sa prstenastim kopčama. U oba slučaja pored pomenutih kopči u grobovima je nađena dugmad sa ka- 
lotastom glavom pomoću kojih se zakopčavala ova vrsta garnitura. Pored toga, u grobu otkrivenom na nekropoli „Više grobalja“ otkrivena je i dugmad sa pločastom glavom kao i pojasni jezičci koji imaju ukrasni karakter. Pojasne garniture ovog tipa u stručnoj literaturi se još nazivaju ,ringschnallencingulum“ i smatraju se predmetima koji su prevashodno korišćeni od strane vojnika. Ovde treba podsetiti da su slične garniture na prostoru Viminacijuma, osim u grobovima muškaraca, nalažene i u grobovima žena i dece.

Na osnovu primeraka iz grobova koji su nađeni zajedno sa novcem, ovaj tip pojasnih garnitura možemo datovati od poslednje trećine II pa do kraja druge trećine III veka. Zbog brojnosti nalaza ovog tipa na tlu Srbije, a naročito u Viminacijumu gde se delovi pomenutih garnitura relativno često nalaze, treba biti otvoren za mogućnost da se na prostoru naše zemlje nalazila i radionica za njihovu proizvodnju.

* The article results from the project: IRS Viminacium, Roman city and military legion camp - research of material and non material culture of inhabitants by using the modern technologies of remote detection, geophysics, GIS, digitalisation and $3 D$ visualisation (no 47018), funded by Ministry of Education, Science and Technological Development of the Republic of Serbia.

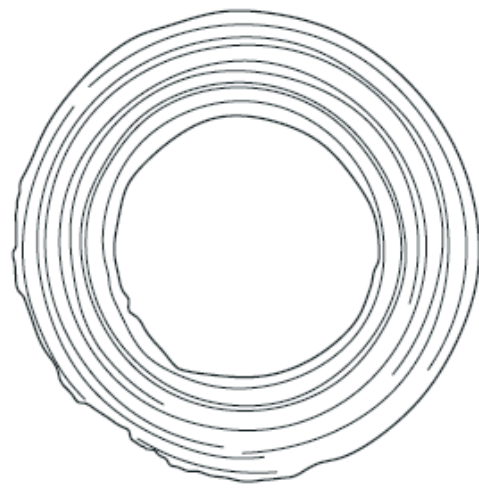

$1 \mathrm{a}$

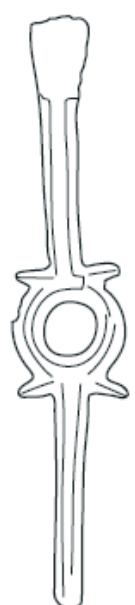

$1 b-c$
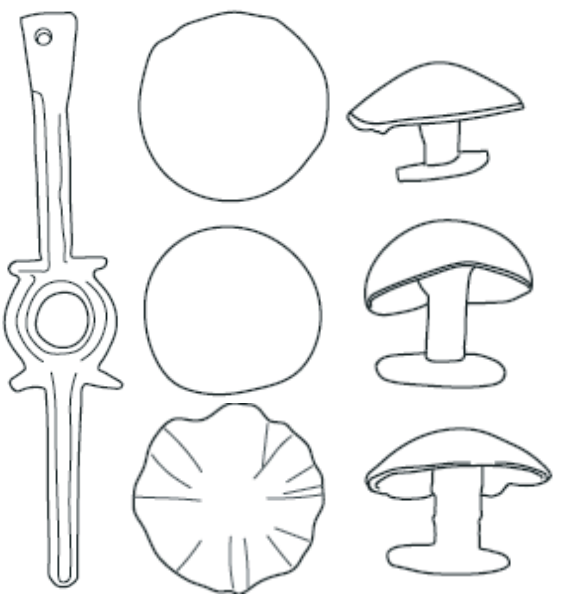

$1 d-f$

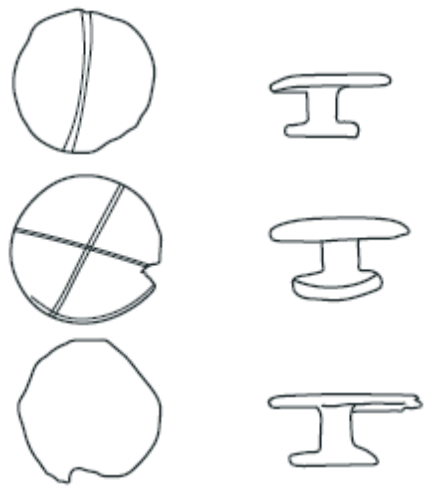

$1 g-\mathrm{i}$

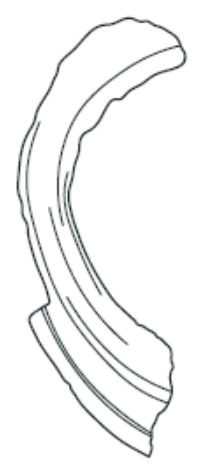

$2 \mathrm{a}$
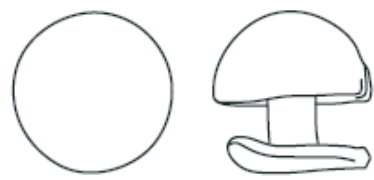

$2 b$

T.I Pojasne garniture iz grobova G-2272, 1a-i; G-10, 2a-b; R 1:1 